\title{
Endobronchial ultrasound in invasive mediastinal staging: A method for all seasons?
}

\author{
Biniam Kidane, MD, MSc, FRCSC
}

\author{
From the Section of Thoracic Surgery, Department of Surgery, Max Rady College of Medicine, University of \\ Manitoba, Winnipeg, Manitoba, Canada. \\ Disclosures: Author has nothing to disclose with regard to commercial support. \\ Received for publication Feb 14, 2017; accepted for publication Feb 15, 2017; available ahead of print April 8, \\ 2017. \\ Address for reprints: Biniam Kidane, MD, MSc, FRCSC, GE-611, 820 Sherbrook St, Health Sciences Centre, \\ Winnipeg, Manitoba R3A-1R9, Canada (E-mail: bkidane@hsc.mb.ca). \\ J Thorac Cardiovasc Surg 2017;153:1565-6 \\ $0022-5223 / \$ 36.00$ \\ Copyright (c) 2017 by The American Association for Thoracic Surgery \\ http://dx.doi.org/10.1016/j.jtcvs.2017.02.051
}

For where is the man of that gentleness, lowliness and affability? And, as time requireth, a man of marvelous mirth and pastimes, and sometime of as sad gravity. A man for all seasons.

-Robert Whittington

(writing about Thomas More)

Czarnecka-Kujawa and colleagues ${ }^{1}$ make a compelling argument for invasive mediastinal staging (IMS) in patients with clinical stage I non-small cell lung cancer. They are upfront that this conflicts with guidelines ${ }^{2,3}$; however, they posit that this is likely related to the lack of rigorous cost-effectiveness data on which current guidelines are based. Using the perspective of a single-payer health system, the authors found that IMS via endobronchial ultrasound transbronchial needle aspiration (EBUS-TBNA) is cost-effective if the prevalence of mediastinal lymph node metastasis (MLNM) is $>2.5 \%$. Some could argue that these findings may not be applicable to different systems. The willingness-to-pay threshold of the authors' system, however, is lower compared with other multipayer systems (eg, United States); thus, the EBUS-TBNA strategy would remain cost-effective in the United States as well as other settings. ${ }^{4}$

The authors make a bold and perhaps controversial statement but provide a methodologically rigorous analysis with robust sensitivity analyses to capture a wide range of MLNM prevalences and EBUS proficiencies. More importantly, their analyses and working assumptions are explicit; above all else, this is crucial because it allows readers to judge for themselves how much they believe/accept the foundational assumptions behind the statistics/methodology. Some assumptions (ie, N2-positive patients on preoperative staging receive trimodality therapy and do better) are controversial. The true impact of this assumption on the overarching conclusions is unclear. Another implicit assumption is that of unlimited EBUS resources; if EBUS is truly a "method for all seasons," how does this impact the ability to provide IMS for all patients in a timely fashion?

The authors provide a brilliant pictorial representation (see Figure 2 in Czarnecka-Kujawa and colleagues ${ }^{1}$ ) of

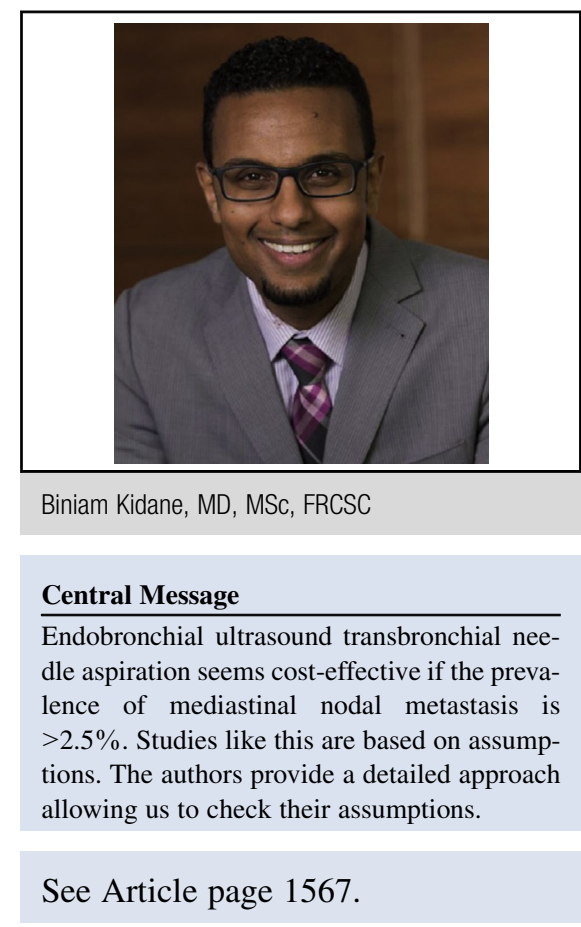

their analyses that allows readers to identify the most cost-effective strategy by finding the intersection of their local MLNM prevalence and EBUS sensitivities. This is a simple and elegant representation of complex interactional concepts and serves as a model of how authors can bring complex findings "down to earth" for clinicians.

Whereas guidelines comment on how things ought to be done, they generally aren't revelatory regarding implementation. ${ }^{2,3}$ Cost-economic analyses such as these provide a window into the factors necessary to bridge guidelines from the realm of the abstract to the realm of local reality. When interpreting these findings, clinicians should consider: (1) What EBUS resources are available? (2) What is your local EBUS sensitivity? (2) What is the prevalence of MLNM?

The first question is particularly important as this study demonstrated EBUS-TBNA was not cost-effective if performed in the operating room. Many centers perform EBUS-TBNA in the operating room with general anesthesia. Reasons for this include increased ease of EBUS-TBNA in fully anesthetized patients as well as resource limitations (ie, hospital will not provide/fund resources). This methodologically robust study potentially can provide a business case for appropriating funds/resources.

In the end, we must remember that studies like this are not infallible and are models based on certain assumptions. 
The devil is in the details, and the authors have provided an honest and detailed approach that allows us to check their assumptions in the appropriate local context. Furthermore, their sensitivity analyses can accommodate a wide range of assumptions, which should empower readers to make more meaningful use of this evidence.

\section{References}

1. Czarnecka-Kujawa K, Rochau U, Siebert U, Atenafu E, Darling G, Waddell TK, et al. Cost-effectiveness of mediastinal lymph node staging in non-small cell lung cancer. J Thorac Cardiovasc Surg. 2017;153:1867-78.
2. Silvestri GA, Gonzalez AV, Jantz MA, Margolis ML, Gould MK, Tanoue LT, et al. Methods for staging non-small cell lung cancer: diagnosis and management of lung cancer, 3rd ed: American College of Chest Physicians evidence-based clinical practice guidelines. Chest. 2013;143(5 Suppl): e211S-250.

3. De Leyn P, Dooms C, Kuzdzal J, Lardinois D, Passlick B, Rami-Porta R, et al. Revised ESTS guidelines for preoperative mediastinal lymph node staging for non-small-cell lung cancer. Eur J Cardiothorac Surg. 2014;45: 787-98.

4. Rintoul RC, Glover MJ, Jackson C, Hughes V, Tournoy KG, Dooms C, et al. Cost effectiveness of endosonography versus surgical staging in potentially resectable lung cancer: a health economics analysis of the ASTER trial from a European perspective. Thorax. 2014;69:679-81. 